\title{
Dialectics of the Phenomenon of Creativity in Neo-traditionalism
}

\author{
Aias Danchai-ool* \\ Tuvan State University \\ 36 Lenin Str., Kyzyl, Republic Tuva, 667000, Russia
}

Received 15.09.2016, received in revised form 03.07.2017, accepted 11.07.2017

The article analyses a special role of the phenomenon of creativity in neo-traditionalism, which is relevant for the post-Soviet space. There are contradictory processes arising due to globalization, which lead to the unification of the value system of traditional culture in accordance with the Western culture. The importance of the cultural and historical tradition for self-identification of the person is revealed. The article also underlines a value of researching the dialectics of an individual and society for understanding the formation of the ethnos tradition. Dialectics of the categories of possibility and reality reveals the essence of the creative process. It is asserted that the natural unity of an individual and society forms the possibility of overcoming the contradictions of the existing being through the phenomenon of creativity.

Keywords: globalization, creativity, culture, ethnos, dialectics, tradition, neo-traditionalism, personality, society.

The article was written within the framework of the project No. 15-21-03002 " $a(\mathrm{~m})$ " of the Russian Foundation for the Humanities "The Dialogue of Civilizations of the Central and Inermost Asia Peoples: History, Culture and Paradigms of Existence".

DOI: 10.17516/1997-1370-0103.

Research area: theory and history of culture.

\section{Neo-traditionalism in Russia at the turn of the $19^{\text {th }}-20^{\text {th }}$ century}

The relevant problems of a modern philosophical thought include a wide range of issues that arise from the cause of globalization. A wide range of scientific research is aimed at the phenomenon of creativity. There is a question about its existence in traditional culture that functions in the context of strengthening intercultural and social ties around the world. One of the attempts to give an answer to the question on creativity in contemporary sociocultural reality is found in the course of nontraditionalism. It manifests itself as a process of restoration and revival of traditions, practices and value system that have emerged during the formation of the core of a particular culture. Neotraditionalism is also associated with the concepts of archaization and traditionalism (Lamazhaa, 2010), but creativity as a special phenomenon is emphasized in it, which allows us to deepen the understanding of all these processes. Studies of

(c) Siberian Federal University. All rights reserved

* Corresponding author E-mail address: dayas@inbox.ru 
neo-traditionalism are found in Russian science, in particular, in the works of C.K. Lamazhaa, Iu.V. Popkov, L.V. Anzhiganova, S.A. Madiukova.

Globalization leads to the unification of socio-cultural space, in which an individual inevitably searches for ways of self-identification. There is self-determination of individuals, social groups and communities (Madiukova, Popkov, 2010). In this system an important role is played by a group that in the modern world manifests itself in the form of a cultural and historical community, an ethnos and a nation. A person necessarily refers to his ethnicity. He sees a clear value system in it, which makes it possible to determine its subject in the general mass of people. A certain spiritual and value basis of culture gives an individual the opportunity to realize his organic unity with society. Appeal to the ethnos occurs in connection with the fact that the boundaries of the world view of a traditional person are designated by the space of ethnos. In particular, it is revealed in the understanding of power of a "land-owner" in the Tuvan culture, whose strength does not extend to other territories (Norenzaian, 2016). Archetypes of traditional culture are preserved in the sociocultural space of society.

In conditions of active unification of cultural values, ethnos loses its own integrity. It is the cultural-historical community that is the carrier of tradition (Akhmetova, 2013). There is a change in the human society as a whole, in a structure of ethnos (Mongush, 2006), in a family (Goncharova, 2010) and an individual personality. In crisis conditions there is a request in society to restore the tradition (Nikolaeva, 2015) as a starting point that enables to form new reality. Neo-traditionalism tends to recreate value systems of the past, stereotypes that could not be transformed into a new reality. This drive for origins creates an ethno-cultural neotraditionalism based on ethnocentrism. Just like any system of subjective being, the desire of the community to restore a bygone tradition is a reason of contradictions that inevitably arises in it (Anzhiganova, 2012). In many regions of Russia we can observe negligent attempts to recreate cultural archetypes in the new public reality, which is actually inevitable in the process of dialectics of the new and the old in culture. Neo-traditionalism has a clear mechanism of formation that is logically structured for the entry of a new socio-cultural reality; frustration in connection with the discrepancy between experience and existing being; a sharp address to tradition; formation of a new paradigm.

\section{The phenomenon of creativity and neo-traditionalism}

The phenomenon of creativity in neotraditionalism is manifested in the transformation of tradition taking into account the innovations that are required by socio-cultural reality. In the changing dialectics of an individual personality and a subject of the cultural and historical community, it creates a new opportunity to overcome the contradictions of the existing being through restoration and adaptation of traditional values. This explains the sharp restoration of traditional social structures in some states that have lost the established political system. The phenomenon of creativity in neo-traditionalism seeks to combine tradition and innovation. It is realized that modernization is necessary to improve the living standard of citizens, but traditional cultures have a need to preserve their "core" that includes values, paradigms and a system of socio-cultural relations (Aksiutin, Anzhiganova, 2010). Without this, ethnos disappears because there is no main force that unites them and makes it clear that a certain group of people has similar worldview attitudes (Naofusa, 1983).

We adhere to the position of Iu.V. Popkov and E.A. Tiugashev concerning ethno-cultural 
neo-traditionalism: "spiritual and practical movement that actualizes the potential of the traditional culture of ethnos at all its levels from the cultural landscape and the economic and everyday culture to the political, legal and spiritual culture" (Popkov, Tiugashev, 2013). A broad understanding of this phenomenon is based on the ontological component of the concept of culture for human existence. This definition is important, because, as the authors note, neo-traditionalism has an "ethnic nature" (Popkov, Tiugashev, 2013). In the Western literature it is difficult to find the concept of neo-traditionalism (in the English dictionaries of the Cambridge University Press (Cambridge Dictionary, 2016), Oxford University Press (Oxford English Dictionary, 2016) and in the Stanford Encyclopaedia of Philosophy (2016) it is absent; in the Encyclopaedia Britannica (2016) it is formulated only in relation to the political activity), since it is most fully disclosed by the example of changes that the socio-cultural postSoviet space is undergoing after the collapse of the USSR. This phenomenon has an ontological nature, which distinguishes it from the Western consumer desire to exploit other cultures. Ethno-cultural groups of the CIS countries felt the urgent need for their own self-determination (Ciubrinskas, 2000), which in other regions of the world was less extensive. Neo-traditionalism has affected all ethnic groups, including the Russian one. Restoration of historical names of places was carried out everywhere. People started to call children traditional names, to restore the traditional way of agriculture, to recreate the structure of social relations (in a family, society), to change the classical secular education system. The phenomenon of neotraditionalism affects the whole structure of the cultural-historical community. It is interesting to know that it is also traced in the modern philosophical thought of Russia, in the address to the religious philosophy of Byzantium, the Old Russian thought, etc.

\section{Dialectics of the phenomenon of creativity}

Understanding the role of the phenomenon of creativity in neo-traditionalism requires an address to the dialectics of the creative process itself. A dialectical method studied in the works of G.W.F. Hegel (2005), as well as the dialecticians of Soviet Russia (Il'enkov, 2010), allows us to connect the complex processes of globalization, changes in a family, the processes of selfdetermination and identification, socialization of an individual personality. The dialectics of categories of opportunity and reality proves that the existing foundation that is in the core of culture actualizes its creative potential through the creative activity of an individual personality (Uvarina, 2006). Heraclitus's understanding of being, as the establishment, structures multiple processes of social being in a consciousness. Considering a person as a specific system makes it possible to link his activity to another system society. The complex interaction of these large and small systems manifests the entire dialectics of relations between an individual personality and a subject of a cultural and historical community, unity in diversity. The specific content of small systems forms the specific content of large systems. Being and human consciousness are the multidimensional open systems. A systemic approach allows us to identify certain levels in thinking that go back from sensory to theoretical methods. A synergetic effect determines the framework for the functioning of consciousness of a single person in accordance with the collective one.

The way of life activity, as experience, of a specific cultural and historical community has been formed for a long time in a natural way. It means that it most closely corresponds to the 
conditions, in which it was formed. The result of creativity includes all the conditions of its creation, from the author to the recipient. Each subject of creativity is most fully "read" in specific conditions. However, sharp modernization and "Westernization" in the modern civilization lead to the fact that the socio-cultural reality does not correspond to the political and economic conditions. The method of thinking as such cannot be correlated with the new reality. The experience accumulated through many centuries cannot be applied in practice, so there is a need in borrowing the experience of other peoples that are already included in the new reality. On the one hand, this challenge makes it possible for a qualitative leap for ethnos, but on the other hand, tradition existed in another timeline, where much was determined from the natural characteristics, which mostly leads to its replacement by foreign cultural elements. Creativity existed as an integral interaction with the surrounding world. The new realities create a paradigm of creativity that cannot always build a holistic picture of the world, but only gives fragments of reality (often virtual). This also includes the issue of human freedom. Creativity in its traditional sense becomes archaic. In the new civilizational characteristics it cannot create a complete picture of the world in each subject. This is evident from publications about the problem of creativity, in which "creativeness" is understood as creativity. But this concept is associated with the creative individualism of modernity with the individual's striving for autonomy and atomization.

Itis generally recognized that the phenomenon of creativity goes beyond the subject. But it also comes out of the temporal characteristics of the process of its implementation. In the process of creativity, the subject goes beyond immanence; it simultaneously contemplates the past and the future and forms a new being. This postulate makes it clear that the subject, external objective conditions and subjective socio-cultural conditions leave their mark on the subject of creativity. Thus, the process of creativity creates a new state of the subject, changes the existing being and forms the new socio-cultural conditions. It is creativity that is an instrument, by which our consciousness is flexible, easily overcomes limitations of the existing being and creates a new reality. Constant actualization is the most important characteristic of the process of creation, which must always form the possibility of its own manifestation. Creativity is a need of consciousness (Iushmanov, 2003) that constantly actualizes the most important paradigms of culture. Like a "fold" in G. Deleuze (Deleuze, 1997) it creates difference between the old and the new, while in itself it is different and creates the new being, thus, it is the basis for the development of culture. A goal of the creative process is not an object, but the subject itself. The object of creativity is not part of a personality, but it remains a product. In this process, from the point of view of objectivity, there is no change in being, but from the point of view of the universal human subject a new state is created. A human, having consciousness, constantly renews himself in the process of creation. An individual personality, as a small system, creates its own new being in the process of creativity, i.e. it changes itself. Accordingly, while changing the small system also changes a larger system. Dialectics of systems proves a direct connection between the creativity of the individual personality and the subject of the cultural-historical community. Creativity requires divergent thinking, which indicates that its forms are endless, since for every person creativity takes various forms. The phenomenon of creativity comes from addressing specific actualized needs and leads to the formation of new qualitatively more complex needs (Chastokolenko, 2009), it is a social activity that builds new types of socio-cultural reality. 
Thus, there is a new being that contains further ways of development. Reality and opportunity, the dialectics of which is carefully revealed in the philosophy of G.W.F. Hegel, are complexly manifested in the creative process. The subject of creativity contains all the possibilities of further creativity; it constantly goes beyond its limits. Thanks to this, a person has selectivity in behaviour (Klochko, 2007).

\section{The phenomenon of creativity - conclusion}

The growing processes of integration in the contemporary world space create certain problems for the formation of an individual's personality, since the individual is formed in conditions of imposing individualization. An individual who does not possess a certain share of responsibility before society cannot exist to the utmost; he constantly feels detachment of subjective being from reality. In these conditions, there is a strong desire for self-identification, regardless of age and social group. The phenomenon of creativity in neo-traditionalism gives the ethno-cultural groups an opportunity to find themselves in the globalized world, while maintaining their own subjectivity and identity. The dialectics of an individual and a culturalhistorical community creates the basis for new forms of creativity that rebuild the tradition. This special phenomenon forms a new being of society and enables self-identification of the individual.

The article is prepared for publication in the framework of the RFH project No. 15-21-03002 "Dialogue of civilizations of peoples of Central and Inner Asia: history, culture and paradigms of existence".

\section{References}

Akhmetova, Sh.K. (2013). Etnichnost' i sotsiokul'turnyi neotraditsionalizm [Ethnicity and socio-cultural neo-traditionalism]. In Omskii nauchnyi vestnik [Omsk Scientific Herald], 2 (116), 263-265.

Aksiutin, Iu.M., Anzhiganova, L.V. (2010). Imperskaia kul'tura: sushchnost', struktura, factory formirovaniia i razvitiia [Imperial culture: essence, structure, factors of formation and development]. In Sibirskii filosofskii zhurnal [Siberian philosophical journal], 1 (8), 59-64.

Anzhiganova, L.V. (2012). Etnicheskii neotraditsionalizm v usloviiakh sotsial'nykh transformatsii [Ethnic neo-traditionalism in conditions of social transformations]. In Mir nauki, kul'tury, obrazovaniia [World of Science, Culture, Education], 6 (37), 438-440.

Cambridge Dictionary. Available at: http://dictionary.cambridge.org/ru (accessed 17 August 2016).

Chastokolenko, Ia.B. (2009). Oppozitsionnye fenomeny tvorchestva $\mathrm{v}$ psikhologicheskikh praktikakh, napravlennykh na aktualizatsiiu kreativnykh vozmozhnostei lichnosti [Oppositional phenomena of creativity in psychological practices aimed at actualization of creative abilities of an individual]. In Vestnik Tomskogo gosudarstvennogo pedagogicheskogo universiteta [Bulletin of the Tomsk State Pedagogical University], 2, 96-100.

Ciubrinskas, Vytis. (2000). Revival of tradition for reconstruction of identity. Lithuanian case. In Journal of Danish Ethographic Society, (40), 19-40.

Deleuze, G. (1997). Skladka. Leibnits i barokko [The fold. Leibniz and the Baroque]. General edition and a final word by V.A. Podoroga. Trans. from French by B.M. Skuratova. Moscow: Publishing house "Logos". 264 p. 
Galvan D. Neotraditionalism. Political science and sociology. In Encyclopaedia Britannica. Available at: https:/global.britannica.com/topic/neotraditionalism (accessed 20 August 2016).

Goncharova, G.S. (2010). Izmenenie semeino-brachnykh otnoshenii i problema ustoichivosti etnokul'turnykh traditsii [Change of family-marriage relations and the problem of the stability of ethno-cultural traditions]. In Novye issledovaniia Tuvy [New studies of Tuva], 3 (7), 117-131.

Hegel, G.W.F. (2005). Nauka logiki [The science of logic]. St. Petersburg: Nauka.

Il'enkov, E.V. (2010). Istoki myshleniia; Dialektika ideal'nogo [The origins of thinking; dialectics of the ideal]. Moscow: LIBROKOM.

Iushmanov, V.I. (2003). O prirode fenomena khudozhestvennogo tvorchestva [On the nature of the phenomenon of artistic creativity]. In Izvestiya RGPU im. A.I. Gertsena [Bulletin of Herzen State Pedagogical University of Russia], 5 (3), 207-216.

Klochko, V.E. (2007). Sovremennaia psikhologiia: sistemnyi smysl paradigmal'nogo sdviga [Modern psychology: the systemic meaning of the paradigm shift]. In Sibirskii psikhologicheskii zhurnal [Siberian Psychological Journal], 26, 15-21.

Lamazhaa C.K. (2010). Arkhaizatsiia, traditsionalizm i neotraditsionalizm [Archaization, traditionalism and neo-traditionalism]. In Znanie. Ponimanie. Umenie [Knowledge.Understanding. Skill], 2, 88-93.

Madiukova, S.A., Popkov, Iu.V. (2010). Sotsiokul'turnyi neotraditsionalizm: vosproizvedenie traditsii i vosproizvodsto etnichnosti [Socio-cultural neo-traditionalism: reproduction of traditions and reconstruction of ethnicity]. In Novye issledovaniia Tuvy [New research of Tuva], 2 (6), 25-39.

Mongush, M. (2006). Modern Tuvan identity. In Inner Asia, 2 (8), 275-296.

Naofusa, Hirai. (1983). Traditional cultures and modernization: Several Problems in the Case of Japan. In Cultural Identity and Modernization in Asian Countries. Available at: http://www2. kokugakuin.ac.jp/ijcc/wp/cimac/hirai.html (accessed 18 August 2016)

Nikolaeva A.Iu. (2015). Neotraditsionalizm i etnofuturizm kak iavleniia v sovremennoi chuvashskoi kul'ture [Neo-traditionalism and ethnofuturism as phenomena in the modern Chuvash culture]. In problemy kul'tury v sovremennom obrazovanii: global'nye, natsional'nye, regional'noetnicheskie [Problems of culture in modern education: global, national, regional-ethnic],127-131.

Norenzaian, Ara. (2016). Theodiversity. In The Annual Review of Psychology, (67), 465-488.

Oxford English Dictionary (OED). Available at: http://www.oed.com/ (accessed 17 August 2016).

Popkov, Iu.V., Tiugashev, E.A. (2013). Etnokul'turnyi neotraditsionalizm i sotsiokul'turnyi podkhod [Ethno-cultural neo-traditionalism and socio-cultural approach]. In Sibirskii filosofskii zhurnal [Siberian Philosophical Journal], 4 (11), 44-49.

Stanford Encyclopedia of Philosophy. Available at: http://plato.stanford.edu/ (accessed 18 August 2016).

Uvarina, N.V. (2006). K voprosu o proiavlenii fenomena tvorchestva v protsesse samoaktualizatsii lichnosti [On the issue of manifestation of the phenomenon of creativity in the process of selfactualization of personality]. In Vestnik of IUUrGU [Herald of SUSU], 16, 160-169. 


\title{
Диалектика феномена творчества
}

\section{в неотрадиционализме}

\author{
А. Данчай-оол \\ Тувинский государственный университет \\ Россия, 667000, Республика Тыва, Кьзыл, \\ ул. Ленина, 36
}

\begin{abstract}
В статье анализируется особая роль феномена творчества в неотрадиционализме, который актуален для постсоветского пространства. Отмечается наличие противоречивых процุессов, возникающих по причине глобализации, которые приводят к унификации иченностной системы традиционной культуры в соответствии с западной культурой. Раскрывается важность культурно-исторической традиции для самоидентификации личности. Подчеркивается ценность исследования диалектики индивида и общества для понимания становления традиции этноса. Диалектика категорий возможности и действительности раскрывает сущность творческого процесса. Утверждается, что естественное единство личности и социиума формирует возможность преодоления противоречий наличного бытия посредством феномена творчества.
\end{abstract}

Ключевые слова: глобализация, творчество, культура, этнос, диалектика, традиция, неотрадиционализм, личность, общеество.

Статья подготовлена в рамках проекта РГНФ №15-21-03002 «а(м)» «Диалог циивилизащчий народов Центральной и Внутренней Азии: история, культура и парадигмы существования».

Научная специальность: 24.00.01 - теория и история культурьл. 